\title{
WHO ARE OUR NATIONAL HEROES BEYOND NATIONAL BORDERS?
}

\section{Lina Gergova}

Assistant Professor at the Institute of Ethnology and Folklore Studies with Ethnographic Museum, Bulgarian Academy of Sciences

Email: lina.gergova@iefem.bas.bg,

\section{Yana Gergova}

An Assistant Professor at the Institute of Ethnology and Folklore Studies with Ethnographic Museum, Bulgarian Academy of Sciences.

Email: yana.gergova@iefem.bas.bg

\begin{abstract}
The focus of this article is on monuments to national heroes built at the initiative of the Bulgarian nation state, political party or migrant community beyond the national borders. Three analytical perspectives are presented: geographical, cultural and social, given that monuments are both physical objects and represent non-physical relations. The place of a monument is essential in the interpretation of its function, reflecting intercommunity negotiations and the views of community elites regarding the place of the in the host society. Another basic issue is who Bulgarian national heroes are abroad, who has selected them, and what means and procedures brought them there. Our hypothesis connects the core of the national celebrations (both pantheon and calendar) within the national territory with its periphery in what is a dynamic system. These reflections are illustrated with three case studies: Botev's monument in Beijing, Vazov's bust in Moscow and Levski's memorial plate in Yeniköy (Romania). An inventory and a map of all the monuments dedicated to these three figures are attached.
\end{abstract}

Keywords: National pantheon, national heroes, monuments, migrant communities, national festivity 


\section{Introduction}

Monuments erected by migrant communities abroad build their national ideology on the example of the nation state, but without its resources and in a multicultural society (Gergova and Gergova 2017: 2). In these conditions, they express the need for cultural dialogue, integration and the goal of preserving identity and national cultural heritage. Monuments erected by migrant communities provide intergenerational continuity and are vital 'social frameworks of memory' (Halbwachs 1992) through which heritage and cultural mechanisms for transmitting significant moments from the past are preserved (Voskresenski 2017: 305).

The Bulgarian Revival Pantheon, established by means of monuments within the national territory, is extremely rich. The Bulgarian Revival Period is fundamental to the national narrative, as it falls within the nineteenth century and reflects the struggles for the independence of both state and church and artistic development, mainly in respect of the national literature. It is therefore not surprising that the pantheon includes revolutionaries, priests, and poets. The Revival pantheon, separated in the 1920s and 1930s, dominates the Medieval pantheon, which, for example, includes saints Cyril and Methodius. It also dominates more recent history, especially since 1989, when many monuments were removed, and others were built or restored.

In our paper, we shall conduct a brief review of monuments and rituals which the Bulgarian state and Bulgarian communities abroad have constructed beyond the present nation state's territory. In order to draw reliable conclusions, we shall present several cases in detail through the prism of three main questions: what part of the Bulgarian national pantheon or the complex of heroes has been presented abroad and how; who initiates the building of monuments and who uses them; and what are the monuments' functions as symbols and/ or markers of Bulgarian identity. Our study's empirical basis is field research carried out with Bulgarian communities in Europe and the USA during the last seven years, as well as an online survey of different countries in South America and Asia.

\section{Why map the monuments abroad?}

In fact, this task involves three particular questions - why mapping? why monuments? and why abroad or in migration? In other words, what precisely will 
mapping monuments beyond the national borders bring to the methodological and analytical perspective?

Mapping is a procedure in social geography that draws the links between social and spatial features (Vaughan 2018: x). These maps usually involve in-depth research, accumulated data and graphic representations as just one result among others. Monument mapping does not exist in people's individual or collective consciousness, being not something objective, but an analytical construct. Although it is based on physical objects, it presents non-physical relations. Mapping can outline several important discourses:

geographical: in which countries and towns have monuments to Bulgarian national heroes been built? This is essential in building the overall picture of contemporary Bulgarian migration and its geographical features, so elaborating the actual map is the key result, not its interpretations. Going further, this would be a map of a global nation - exactly of the nation in the classic meaning of this word (Smith 1995). Such a record transforms the amount of memorial representations into a living organism (Vaughan 2018) with its own dynamics and inner interactions.

cultural: who are these heroes? While we do not intend to indulge in a competition, we argue that a quantitative analysis will develop the understanding of the national pantheon and open up new discussions or contribute to the already ongoing ones. We therefore address issues of the possible embodiment of the national idea in a single figure, the inner hierarchy of the pantheon within the nation-state and beyond its borders, ritual conservatism, etc.

social: this dimension investigates Bulgarian migrant communities'social capital, their leaders' policies and views towards migrant organization, their calendars and activities in space, community activities, the links between them, and their place within the host society.

Benedict Anderson's idea of extra-local memories and their function in the mobilisation of an 'imagined community' of nationhood (Anderson 2006) considers the spatial embodiment of national ideas with regard to monuments and memorials being realised extra-spatially. Regarding monuments, this does 
not mean that space does not matter, but that the monument produces and identifies the place in which it is set, not vice versa. This is a perspective focusing on the instrumentalization of the monuments that treats them not just as a cultural phenomenon or a physical object of veneration or a shared group symbol (Halbwachs 1992). Here, monuments are considered to be rhetorical topoi (Boyer 1994), being outside their usual homely national space and having left the national narrative embodied in memorial sites and figures. Studying monuments constructed because of migration rather reflects vernacular and official models of declaring a presence within the public space and fitting the community national narrative in the host society's memorial landscape. Nuala Johnson insists that the spatiality of memory is not only mirrored in the physical distribution of commemorative sites but also in the interpretative apparatus embedded in them (2002: 295). It is thus interesting to uncover the ways in which a migrant community or nation state across national borders try to integrate their interpretative apparatus to that of the host or to challenge it.

The spatial features of a monument or a group of monuments constitute their meaning both as a physical location and a mode of interpretation (Johnson 1994, Johnson 1995). The exact place of a monument is essential in interpreting its function of reflecting intercommunity negotiations and community's elites' views on the place of the community within the host society - place as both physical and social, as well as performative cultural traditions.

In some cases, it is not the migrant community but the nation state that had built memorial spaces outside its territory. Such gestures open up further discussions contesting or acknowledging theories of nationalism. Regarding space, crossing national borders and exporting national narratives or grounding them outside the national territory highlight two main issues: the place and the figure. Within what significant space and which national hero or symbol has the nation state made efforts regarding place? In short, as national borders are essential for the nation state, crossing them and exporting nationhood and its attributes leads us to emphasize the issue of space.

\section{Literature review}

Studies of migrant monuments and memorial practices predominate in these gestures, dedicated to the nation state, to conquer territory beyond its borders, as well as building monuments and carrying out commemoration rituals. However, this direction develops particularly in the context of memory studies and 
the notion of transnational memory (see a detailed palette of perception in De Cesari and Rigney 2013; Radstone 2011). One inspiring collection of a variety of articles has been edited by Sabine Marschall, who, in the Introduction, considers the potential of the study of migrants' monuments to involve the 'emergence of a new type of collective memory that is produced at the interface of two or more memorial cultures' (2020: 7). She goes even further, being concerned by processes of integrating migrant memories and 'accommodating their public representation in monuments, especially in places conventionally reserved for the commemoration of national memory' (ibid.: 11). Loretta Baldassar (2006) also reflects on the history-contesting potential of migrant monuments in her case studies of Italy and Australia. In her own study, Anne-Marie Fortier (2000) opened up an analytical perspective on performative culture and suggested that belonging (national or ethnic) and institutional identities could be performative besides being physically present. Surprisingly in the perspective of this topic, in-depth historical studies on São Paulo's and Buenos Aires' sculptural representations of Syrian mythologies have been published by Olivia Wolf $(2017,2020)$. All these studies bring out the issues of the messages and discussions that monuments and their lives produce, the connection between space and performance, individual and institutional stakeholders, and the national, international and transnational domains.

In the Bulgarian literature, few studies explore monuments constructed abroad by migrant communities or the Bulgarian state, although this activity has been flourishing in recent decades. Besides the current research presented here, not many scholars have studied the issue of migrants' monuments. Nikolay Vukov and Mariyanka Borisova observed and described the unveiling of Vasil Levski's monument in Chicago, choosing as its analytical key its role as a place and reason for the migrant community to gather together (2017: 26-7). In their paper on Bulgarian migrants in Spain, Vukov and Valentin Voskresenski consider monuments to be an aspect of the tangible cultural heritage that the community attempts to create in order to declare its presence in the physical space. Perhaps the only cross-border study of the practice of migrant communities in building monuments is that of V. Voskresenski, part of the collective monograph on cultural heritage in migration (Воскресенски 2017). His theoretical framework is based on the concept of collective memory (Halbwachs 1992), and he suggests a typology of memorial places and monuments built abroad by both the 'old' and 'new' migration. As part of other joint publications, 
Svetlozar Eldarov and Rayko Nikolov contributed to the history of building the Sts Cyril and Methodius monument in Rome (Eldarov 2002, Nikolov 1998).

Regarding monuments built by the nation state beyond its national borders, a study particularly on this issue has been conducted by the current article's authors on Bulgarian monuments in Rome and Bucharest, taking into account their history, the rituals and audiences they serve, and their role within the host society (Gergova and Gergova 2017). In Rome's case, among other Bulgarian places in Italy, another in-depth article by Yana Gergova describes the interactions between migrant festivities and state initiatives (Гергова 2019). From the point of view of school life and festivities, the monument to Saints Cyril and Methodius in Thessaloniki has been discussed by Tanya Matanova ( 2017). Another case of narrow partnership between a local migrant community and state representatives is the 24th May celebrations in Mikulčice (see Borisova 2019). Several scholars have studied Bulgarian communities abroad and their festivities, but unfortunately in almost all these cases there are no monuments (sеe Янкова 2014).

Although many analyses have been accumulated in both Bulgarian and international scholarship, we will not deal here with the theme of soldiers and war monuments because it is not connected with exporting symbols and images but rather provides the historical basis of the collective memory. Focusing on this theme would move us away from the concepts of imagined communities and the mapping of symbolic sites because war memorials and graveyards, although often mythologised and overloaded with meanings and ideas, are literally connected with their locations.

\section{The Bulgarian Revival Pantheon within and beyond Bulgaria}

As in most nations born in the nineteenth century out of liberation and the wars that were defined as unifying or liberating in their respective historiographies (e.g. Hungary, Ukraine, Estonia, etc.), the heroic pantheon of the Bulgarian Revival, that inventory of heroes and narratives, refers precisely to the period of greatest political and artistic audacity. Though the Bulgarian state is also medieval, the community of great figures also includes Saints Cyril and Methodius and their disciples, and a great variety of rulers and scholars, most of them Orthodox saints. However, they are perceived from the distance of time, and their deeds are not considered remarkable feats. On the contrary, Revival personalities stand for bravery, sacrifice, and devotion to national lib- 
erty. Scholarship of significance to the Revival period in the Bulgarian national narrative and its symbols have been dealt with by Roudometof 2002, Aretov 2006, Grigorov 2007, etc. Here we would like to add another perspective, that of attempts to export this narrative and its characters.

The leading figures in the Bulgarian Revival Pantheon could be identified as follows: Vasil Levski, the leader and inspirer of the armed struggle for freedom; Hristo Botev, the poet revolutionary who acquired the greatest importance during the socialist period because of his communist ideas; Ivan Vazov, commonly called the Patriarch of the Bulgarian literature; less often Paisiy Hilendarski, a monk and the author of the first Bulgarian history book; and Georgi Sava Rakovski, who established the first armed units of volunteers, etc. The first two, Vasil Levski and Hristo Botev, were friends and fellows in their lives, having spectacular biographies and coming to tragic ends. Levski was captured and hanged by the Ottoman authorities, while Botev died in battle during the April uprising of 1876. In many images and spaces, they are placed together visually, but in the construction and inclusion of their images as part of the national pantheon, there are differences that become particularly visible beyond the national borders (see further below). To outline general trends, we will limit the details and emphasize instead the monuments to Levski, Botev and Vazov. Whilst in Bulgaria monuments to them have been erected in every town and city, abroad things are different.

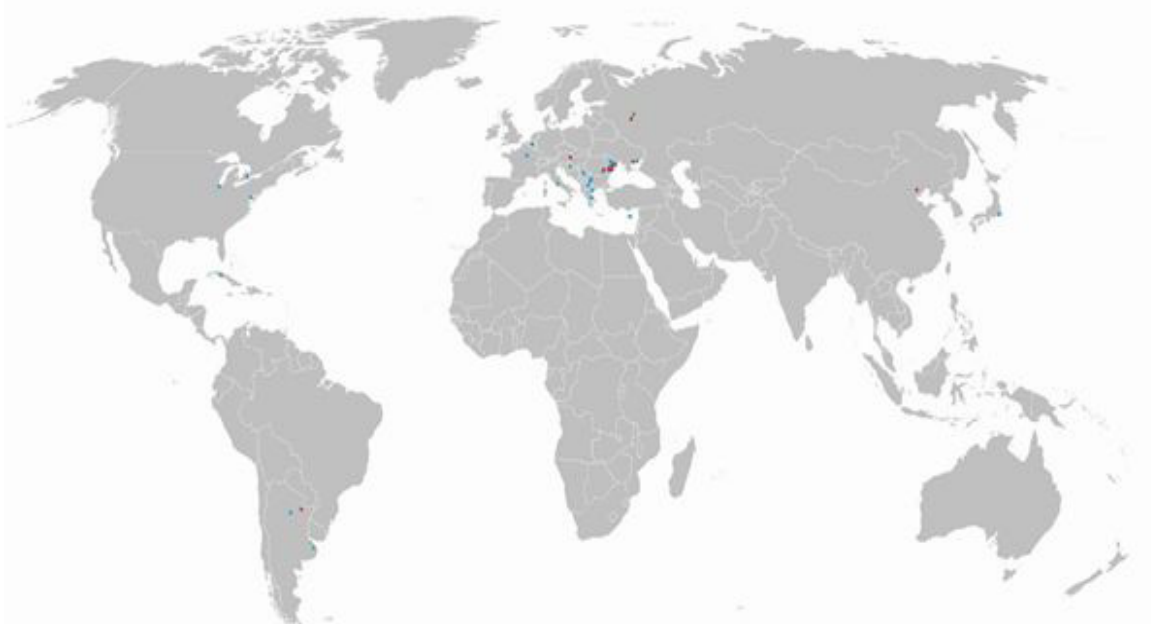

Figure 1. Map of Levski's, Botev's and Vazov's monuments built abroad. Yana Gergova, Lina Gergova, 2020 
The blue points mark monuments to Levski, usually busts but also memorial plaques. These monuments are concentrated in countries near Bulgaria, mostly to the north-east. Some of them are located in not very accessible spaces on Bulgarian embassy premises (as in Washington) or in an embassy's reception area (as in Tokyo). We have not considered those that are not in public open spaces (see also Marschall 2020:3). In red are the monuments to Botev, of which all but one are busts. They are also concentrated in nearby countries, probably because Botev and Levski are connected biographically with these territories, namely East Romania, Moldova, and Ukraine, where Bulgarians still live today. In green are the monuments to Vazov, two of which are still in progress. Their places are not connected with the subject's life: instead his figure represents Bulgaria symbolically, mainly its literary heritage.

There are also monuments to other Revival figures worldwide, mainly in other European countries, for example, to Georgi Sava Rakovski, Lyuben Karavelov, and Peter Beron. However, they are sporadic and deserve a separate in-depth study.

Choosing the names of Bulgarian migrant (also called Sunday) schools and associations is a linked issue that contributes to analysing the institutional representations of the Revival pantheon within the host society. School names are significantly more diverse and are often not of heroes or historical personalities but abstractions like Homeland (Sidney, Malaga, etc.), Patriotism (Rodolyubie, Toronto, Rabat, etc.), ABV (the first letters in the Cyrillic alphabet) or Alphabet (Azbuka) (Amsterdam, Helsinki, Dublin, Xanthi, etc.). Of about 200 Sunday schools all over the world, only five are named after Ivan Vazov, eight after Hristo Botev and sixteen after Vasil Levski. A fruitful comparison might be conducted of institutional figures and images in Bulgarian communities abroad in a separate study.

\section{Initiatives}

Tracing the history of each monument outlines some trends. In general, Vasil Levski's monuments resulted from an initiative exported from Bulgaria and realized after the late 1990s. The initiative extends to at least three continents, but mainly targets places connected with the hero's life. Old and new migrant communities prefer the image of Levski. The All-Bulgarian Vasil Levski Committee is very active, raising funds and erecting monuments not only abroad. Political parties and patriotic organizations also initiate the placing of memo- 
rial plaques. The results of the initiative of the All-Bulgarian Committee 'Vasil Levski', the Vasil Levski Foundation, the Bulgarian Genealogical Society 'Rodoznanie' and the portal Kafene.bg under the title 'Let's count the monuments of Levski', launched on 3 March 2009, give a relatively clear picture regarding the number and location of Vasil Levski's monuments both in Bulgaria and abroad. The aim of the initiative was to gather information on places of monuments or bas-reliefs of Vasil Levski, and the results include a little over 140 monuments.

Many of the monuments abroad are copies of two of the most popular ones in Bulgaria: the bas-relief of the monument called Levski in downtown Sofia, which is among the oldest monuments in the country, and the bust in the Boris garden in Sofia, a model for a memorial place of the national pantheon as a whole. We believe that it is due to the model that these monuments abroad have been built: with donations, small amounts are collected, and it is cheaper to purchase a copy.

The monuments to Hristo Botev are diverse in terms of their imaginaries, and they refer to monumental international interactions. Some of Botev's monuments are part of complexes putting together poets and authors from various countries - such memorials are located in Beijing, Bucharest, Gols, etc. In these cases, Botev has been just one representing Bulgaria's literary heritage, sometimes even initiated by the host country. Elsewhere, as in Rome, Moscow and Zagreb, the figure of Ivan Vazov was preferred for this purpose. Botev's monuments also mark stages in his biography in Romania, Moldova and Ukraine, or else his name was selected to unify the local migrant communities - as a name of an organization that was subsequently embodied in a monument. Despite this, in most cases Vazov is the state's choice. The three monuments are relatively new, having been erected in recent ten years. What they have in common is that they are placed in urban spaces dedicated to literature, and that Vazov has been chosen due to his image as the Patriarch of Bulgarian literature.

Here we would like to emphasize once again the fondness of the socialist regime for Hristo Botev, which has also been exported. Several monuments to the poet were erected during socialist times or somewhat afterwards, in Bucharest, Ismail, Zadunaevka, and Russia at the 66th $\mathrm{km}$ of the autobahn Kievskoe shosse, where we see his emblematic words: 'He who falls in freedom's fight, he does not die', supplementing the memorial to a Bulgarian who fought in the Red Army. 
Who are Our National Heroes beyond National Borders?

\begin{tabular}{|c|c|c|}
\hline $\begin{array}{l}\text { Place of the } \\
\text { monument }\end{array}$ & Year of erection & Initiator; Author \\
\hline \multicolumn{3}{|l|}{ Vasil Levski } \\
\hline $\begin{array}{l}\text { Argentina, Buenos } \\
\text { Aires }\end{array}$ & before 2012 & No information \\
\hline $\begin{array}{l}\text { Argentina, Las } \\
\text { Breñas }\end{array}$ & before 2013 & No information \\
\hline Belgium, Brussels & 2010 & $\begin{array}{l}\text { Representative } \\
\text { of the Bulgarian } \\
\text { embassy, Bulgarian } \\
\text { school and local } \\
\text { migrant com-mu- } \\
\text { nity }\end{array}$ \\
\hline Greece, Athens & 2018 & $\begin{array}{l}\text { Bulgarian migrant } \\
\text { community }\end{array}$ \\
\hline $\begin{array}{l}\text { Greece, Thessa- } \\
\text { loniki }\end{array}$ & 2004 & $\begin{array}{l}\text { All-Bulgarian } \\
\text { Committee and } \\
\text { Foundation 'Vasil } \\
\text { Levski', Bulgarian } \\
\text { students in Thes- } \\
\text { saloniki }\end{array}$ \\
\hline Canada, Bramton & 2017 & $\begin{array}{l}\text { Donors coordinat- } \\
\text { ed by the Bulgar- } \\
\text { ian Church }\end{array}$ \\
\hline Cyprus, Nicosia & 2012 & $\begin{array}{l}\text { Donations, the } \\
\text { Bulgarian embassy, } \\
\text { All-Bulgarian } \\
\text { Committee and } \\
\text { Foundation 'Vasil } \\
\text { Levski' }\end{array}$ \\
\hline
\end{tabular}




\begin{tabular}{|c|c|c|}
\hline Cuba, Cienfuegos & 1981 & $\begin{array}{l}\text { Bulgarian workers, } \\
\text { built factory with } \\
\text { the same name }\end{array}$ \\
\hline $\begin{array}{l}\text { North Macedonia, } \\
\text { Skopje }\end{array}$ & No information & No information \\
\hline Moldova, Chișinău & No information & $\begin{array}{l}\text { 'Vasil Levski' } \\
\text { Foundation. Au- } \\
\text { thor: Prof. Veli- } \\
\text { chko Minekov }\end{array}$ \\
\hline Moldova, Parcani & 2008 & $\begin{array}{l}\text { Erected on the oc- } \\
\text { casion of } 100 \text { years } \\
\text { of independence of } \\
\text { Bulgaria }\end{array}$ \\
\hline Moldova, Taraclia & 2018 & $\begin{array}{l}\text { Alexander Bori- } \\
\text { mechkov, public } \\
\text { figure and associ- } \\
\text { ate of the city hall } \\
\text { in Taraclia }\end{array}$ \\
\hline Moldova, Tvardița & before 2018 & No information \\
\hline $\begin{array}{l}\text { Romania, Bucha- } \\
\text { rest }\end{array}$ & 2001 & $\begin{array}{l}\text { All-Bulgarian } \\
\text { Committee and } \\
\text { Foundation 'Vasil } \\
\text { Levski' }\end{array}$ \\
\hline Romania, Yeniköy & 2011 & $\begin{array}{l}\text { Political party } \\
\text { Vazrazhdane, busi- } \\
\text { nessman Milen } \\
\text { Vrabevski }\end{array}$ \\
\hline USA, Washington & No information & No information \\
\hline USA, Chicago & 2015 & $\begin{array}{l}\text { 'We, the Bulgarians } \\
\text { around the world' } \\
\text { Foundation }\end{array}$ \\
\hline
\end{tabular}




\begin{tabular}{|c|c|c|}
\hline Serbia, Beograd & 2007 & $\begin{array}{l}\text { National asso- } \\
\text { ciation 'Georgi } \\
\text { Stoykov Ra-kovski' } \\
\text { and All-Bulgarian } \\
\text { committee 'Va-sil } \\
\text { Levski' }\end{array}$ \\
\hline Serbia, Bosilegrad & 2005 & $\begin{array}{l}\text { Donation, incl. } \\
\text { Municipality of } \\
\text { Pernik }\end{array}$ \\
\hline $\begin{array}{l}\text { Serbia, Dimitro- } \\
\text { vgrad }\end{array}$ & 2014 & $\begin{array}{l}\text { The mayor of the } \\
\text { town }\end{array}$ \\
\hline France, Paris & 2007 & No information \\
\hline $\begin{array}{l}\text { Ukraine, Berdy- } \\
\text { ansk }\end{array}$ & 2007 & $\begin{array}{l}\text { Association of } \\
\text { the Bulgarians in } \\
\text { Ukraine, All-Bul- } \\
\text { garian Committee } \\
\text { and Foundation } \\
\text { 'Vasil Levski' }\end{array}$ \\
\hline Japan, Tokyo & 2012 & $\begin{array}{l}\text { 41st National As- } \\
\text { sembly and 'Vasil } \\
\text { Levski' Foundation } \\
\text { on the occasion of } \\
175 \text { years since the } \\
\text { birth of the Apos- } \\
\text { tle. At the Bul- } \\
\text { garian embassy. }\end{array}$ \\
\hline
\end{tabular}

\begin{tabular}{|l|l|l|}
\hline Austria, Gols & 1999 & $\begin{array}{l}\text { Austrian Professor } \\
\text { Nick Titz; Author: } \\
\text { Kunyo Zhelev }\end{array}$ \\
\hline
\end{tabular}




\begin{tabular}{|c|c|c|}
\hline $\begin{array}{l}\text { Argentina, Chaco, } \\
\text { Roque Sáenz Peña }\end{array}$ & End of the 1990s & $\begin{array}{l}\text { Civil Association } \\
\text { 'Bulgarians in Ar- } \\
\text { genti-na', Bulgarian } \\
\text { Association 'Hristo } \\
\text { Botev' from Roque } \\
\text { Sáenz Peña }\end{array}$ \\
\hline China, Beijing & 2006 & $\begin{array}{l}\text { On the occasion of } \\
\text { the celebration of } \\
\text { the } 60 \text { th anniver- } \\
\text { sary of the begin- } \\
\text { ning of dip-lomatic } \\
\text { relations between } \\
\text { China and Bul-gar- } \\
\text { ia. Author: Prof. } \\
\text { Yuan Xikun }\end{array}$ \\
\hline Romania, Brăila & No information & No information \\
\hline $\begin{array}{l}\text { Romania, Bucha- } \\
\text { rest }\end{array}$ & No information & No information \\
\hline Russia, Kiev road & $1985(?)$ & No information \\
\hline Ukraine, Artsyz & 2010 & Community \\
\hline Ukraine, Botievo & 2005 & No information \\
\hline $\begin{array}{l}\text { Ukraine, Saduna- } \\
\text { jiwka }\end{array}$ & 1991 & $\begin{array}{l}\text { Author: Georgi Ne- } \\
\text { dyalkov. There is a } \\
\text { memorial plaque } \\
\text { on the house where } \\
\text { Botev has lived. A } \\
\text { memorial museum } \\
\text { was opened in } \\
2008 \text { (branch of the } \\
\text { Odessa Lit-erature } \\
\text { Museum) }\end{array}$ \\
\hline
\end{tabular}




\begin{tabular}{|l|l|l|}
\hline Ukraine, Izmail & 1978 & $\begin{array}{l}\text { In reference to the } \\
\text { 100th anniversary } \\
\text { of the liberation of } \\
\text { Bulgaria and 30th } \\
\text { anni-versary of } \\
\text { the signing of the } \\
\text { Friendship, coop- } \\
\text { eration and mutual } \\
\text { aid between USSR } \\
\text { and Bulgaria. } \\
\text { Author: Mihail Ne- } \\
\text { dopak }\end{array}$ \\
\hline Ukraine, Odessa & 2009 & $\begin{array}{l}\text { All-Ukrainian } \\
\text { public organiza- } \\
\text { tion 'Con-gress of } \\
\text { the Bulgarians in } \\
\text { Ukraine' }\end{array}$ \\
\hline Ivan Vazov & 2010 & \\
\hline Italy, Rome & & $\begin{array}{l}\text { The Ministry of } \\
\text { Culture of Bul- } \\
\text { garia (Min-ister } \\
\text { of Culture Vezhdi } \\
\text { Rashidov); donat- } \\
\text { ed funds from } \\
\text { Bozhidar Petraki- } \\
\text { ev; Au-thor: Prof. } \\
\text { Velichko Minekov }\end{array}$ \\
\hline
\end{tabular}




\begin{tabular}{|l|l|l|}
\hline Russia, Moscow & 2011 & $\begin{array}{l}\text { The Ministry of } \\
\text { Culture of Bul- } \\
\text { garia (Min-ister } \\
\text { of Culture Vezhdi } \\
\text { Rashidov); Author: } \\
\text { Levon Baltayan }\end{array}$ \\
\hline Croatia, Zagreb & 2018 & $\begin{array}{l}\text { Bulgarian embassy, } \\
\text { an idea inspired by } \\
\text { Vazov's long-stand- } \\
\text { ing friendship with } \\
\text { Croatian novelist } \\
\text { and translator Dr } \\
\text { Fran Gundrum- } \\
\text { Oriovac }\end{array}$ \\
\hline $\begin{array}{l}\text { Argentina, Las } \\
\text { Breñas / Berisso }\end{array}$ & $?$ (project stage) & $\begin{array}{l}\text { Due Part of twin- } \\
\text { town relationship } \\
\text { be-tween Las } \\
\text { Breñas (Argentina) } \\
\text { and Botev's home- } \\
\text { town Sopot (Bul- } \\
\text { garia) }\end{array}$ \\
\hline $\begin{array}{l}\text { Moldova, Colib- } \\
\text { abovca }\end{array}$ & 2007 & $\begin{array}{l}\text { No information } \\
\text { ind }\end{array}$ \\
\hline
\end{tabular}

Figure 2. Inventory of all Levski's, Botev's and Vazov's monuments abroad. Yana Gergova, Lina Gergova, 2020. 


\section{Practices}

Of course, as well as in the country, monuments create ritual space, which is being realized at particular calendrical moments. In the nation state, the monuments to these three Revival figures are being visited and become festive centres on the dates of their birth and death. However, Ivan Vazov is not celebrated solemnly, and his biographical moments are not part of the national calendar. Abroad, these monuments are often central to the festive calendar of the migrant community in general, and they concentrate the attention of the local society on the presence of Bulgaria as a state. For instance, the monument to Levski in Athens and those to Vazov in Zagreb were erected just two years ago but have already accrued various commemorative practices and are involved in the festive and cultural calendar of the local migrant community. One such example is the celebration of the Day of Bulgarian Education and Culture and the Slavic Script at the monument in the Croatian capital, which involves the laying of wreaths and flowers, greetings, and a concert with the participation of students from the Bulgarian Sunday School 'Ivan Vazov'.

\section{Case studies}

We chose to give three separate examples to illustrate the uses of monuments abroad and their role for the local community. The three monuments represent each of the three Bulgarian Revivalists. They are situated in different countries, each with certain specifics in terms of historical connections with the depicted person initiating the erection of the monument, providing symbolic capital for Bulgarian migrants and Bulgarian tourists.

\section{Case 1: The monument to Hristo Botev in Beijing, China}

The bust of this Bulgarian revolutionary in Beijing was unveiled at a solemn ceremony in November 2006 to mark the 60th anniversary of the beginning of diplomatic relations between China and Bulgaria, in Chaoyang Park on the Alley of Greats, along with 12 other sculptures (e.g. Mahatma Gandhi, Karl Marx, Ignacy Jan Pedrevski, etc.). In 2009, on the eve of 2 June, Botev Day and for Those Who Died for Bulgaria's Freedom and Independence, a copy of the bust was donated by the Chinese delegation to the home town of the revolutionary poet Kalofer. It is placed in front of the town hall in the central part 
of the city. The author of both sculptures was the Chinese sculptor Prof. Yuan Xinkun, who in 2019 was nominated for the honorary badge of the Ministry of Foreign Affairs Golden Laurel Branch for his contribution to improving Bulgarian-Chinese relations. It is interesting that the monument depicts Botev at a more mature age, which, due to his tragic death at the age of 28 , he did not live to see. It is believed that, through deliberate ageing, the author wanted to present the hero's genius, which, according to Chinese philosophy, is inherent only in an elderly man, not a 28-year-old young man.

For almost 15 years, the area around the monument has been the principal place where festive celebrations related to 24 May (Day of Bulgarian Education and Culture and Slavic Script) and 2 June (Botev Day and to Those Who Died for the Freedom and Independence of Bulgaria) are held. Celebrations usually include official speeches, flowers and wreaths laid by guests, as well as concert performances and recitals performed by students from the local Bulgarian Sunday school 'Sts Cyril and Methodius'. All official delegations present flowers and wreaths in front of the monument during their visits to the Chinese capital.

Unlike most celebrations at other Bulgarian monuments abroad, this is marked by the participation not only of representatives of the Bulgarian migrant community and officials in Beijing, but also of Chinese institutions. For example, at each event, the students of Bulgarian studies at the Beijing University of Foreign Languages and Tianjin University of Foreign Languages are among the main participants and prepare a program of songs and poems about Botev and Bulgaria.

\section{Case 2: The monument to Ivan Vazov in Moscow, Russia}

The monument to this Bulgarian writer in Moscow was unveiled on 3 June 2011, in the presence of the Minister of Foreign Affairs of the Republic of Bulgaria, Nikolay Mladenov, Deputy Minister of Culture of the Russian Federation, Andrei Busigin, writers, intellectuals and many citizens. The monument was created by the Armenian sculptor Levon Baltayan. It is located in the atrium of the Library of Foreign Literature among the busts of world-famous people such as Dmitry Likhachev, Charles Dickens, Abraham Lincoln, Simón Bolívar, Sándor Petöfi and others. The activity of the Bulgarian Cultural Institute in Moscow, which has been housed in the library building since 2012, is also connected with its installation. At its initiative, the monument was included in the cultural 
calendar of the community (both migrant and local) mostly through ceremonial events with visits by Bulgarian artists, screenings of documentaries, the opening of exhibitions and literary readings. Previously, every year on Enlightenment Leaders Day on 1 November, Bulgarian diaspora representatives, including students from the Bulgarian Sunday school, students and teachers at Moscow universities, and associates of various Bulgarian missions in the city, gather to worship the monument and lay flowers. A festive literature programme, which includes readings of his works, exhibitions of publications, stories about Vazov's life and his relationship with Russia, etc., also celebrate the writer's anniversary. One of the most exciting events, organized for the 169th anniversary, is a walk through places linked to Bulgarian history and culture in the Russian capital, and its starting point was the very monument of Ivan Vazov.

A year before the monument to the writer was erected in the Russian capital, another was unveiled in Rome, on Piazza Thorvaldsen, near Borghese Park, at the initiative of the then-Minister of Culture Vezhdi Rashidov, in the presence of the Bulgarian and Italian prime ministers, Boyko Borissov and Silvio Berlusconi. Although for the short time of its existence the monument has become a landmark for Bulgarians - both for the local migrant community (who initiate various celebrations and events in front of it) and for tourists - many Bulgarian visitors to the city come to take pictures. Gradually, the monument became an important site within the celebrations and was on the route of the government delegation on 24 May, the Day of Bulgarian Education and Culture and the Slavic Script. It is often preceded by the Enlightenment Leaders Day - 1 November (Gergova <aand Gergova 2017: 12-13). The picture is similar to the latest monument of Ivan Vazov, that in Zagreb, which has already acquired a symbolic appearance as the 'Bulgarian place' in the city, around which festive programs of celebrations and the pilgrimages of official delegations develop.

Going back to the Moscow case, it is striking that, unlike in Rome and Zagreb, the Bulgarian diaspora consider the monument less central as a place of commemoration, the events held there being connected rather with the Bulgarian Cultural Institute's activities. This may be because the monument is located in the closed space of the library yard, making it a 'possession' of the institute. Vazov's monument also has to compete with other monuments related to Bulgarian history that traditionally host anniversaries and public events. 


\section{Case 3: Vasil Levski’s monument in Yeniköy (Mihail Kogălniceanu), Romania}

The idea of building such a monument was born in 2007 within the environment of the nationalist TV channel SKAT and party VMRO. The initiator was the historian and at that time vice-president of the party, Kostadin Kostadinov, who comes from Dobrudzha and is interested in the topic of Northern Dobrudzha (today in Romania) as both a historian and a politician. During the filming making of his film about Bulgarians in Northern Dobrudja, a 'Forgotten Land', he discovered that the old Bulgarian school building was still preserved in the village of Yeniköy.

In 2010, VMRO activists from Varna and Dobrich and scholars from Dobrich Regional History Museum carried out a research expedition in Northern Dobrudzha. They started an initiative to create a monument to Vasil Levski. Vasil Levski was a teacher at the Bulgarian school in the village of Mihail Kogălniceanu, formerly Yeniköy, in 1866-1867,. After a campaign consisting of raising funds and negotiating with the local authorities in Tulcea and Mihail Kogălniceanu, the memorial plate was unveiled on 6 July 2011. The date was not chosen by chance, but is Levski's old-style birth date. The plate was funded by Milen Vrabevski, who is famous for his projects building and restoring monuments and organising patriotic gatherings for Bulgarians from Bessarabia. The plate was placed on the former school wall, now a clinic. The unveiling event was attended by many guests from Varna and Dobrich, mainly activists in VMRO. A local Bulgarian folk group took part, and a priest consecrated the memorial plate.

Every year, on the date of the hero's birth, even in 2020 when pandemic measures restricted border crossings, modest memorial ceremonies take place. They are usually organised by VMRO or Kostadinov's new party, Vazrazhdane ('Revival'). Ordinary tourists also visit the monument on their way to other places in Romania, place flowers there or just take a photo at the plate. The plate is an essential stop in trips under the title 'In Levski's footsteps' taken in Romania. According to the memorial sign's ideologists, it is loaded with the function 'to remind the locals and all Bulgarians of the most beloved son of our nation' (TV Skat, 08.07.2011). However, it is also considered a step in recovering the memory of Bulgarian historian personalities who are connected with Dobrudzha, such as Khan Asparuh, Dobrotitsa, Stefan Karadzha and Pop Hariton. 


\section{Conclusions}

At the beginning of the article, we set out three main analytical purposes in mapping Bulgarian migrants' monuments worldwide: geographical, cultural, and social. They cannot be separated, given that all the meanings and functions of the monuments are intertwined, so our conclusions consider all of them together. In migration settings, we can speak about the concentration of national pantheons in one or two figures. Since this cannot be fully recreated, only the most significant ones are chosen, but we see that the top of the pyramid is reserved again for Levski, Botev and Vazov, who stand on it in descending order. Considering the cultural gestures and social practices of the first-generation migrants, it is not surprising to see them copy or bring with them the nationalist matrixes of the pantheon, such as festivity, education, etc. However, here we have also mentioned monuments in South America built by the heirs of migrants from the early twentieth century. So here, we have two possibilities that are not mutually exclusive: first, the matrixes have not changed much in the last century; and second, communication with the homeland ensures that the nationalist reflexes are updated.

The three figures become symbols - each of them individually in the particular space - of the whole nation and the context of the national festivity. While in Bulgaria each of them has its own separate time in the calendar, in migration, many feasts from the national calendar are celebrated at the only monument, especially the national holiday on 3 March. Personal 'specialisation' and biography cease to matter, and one figure concentrates the whole palette of national heroes. Nevertheless, monuments that have a biographical connection with their region are considered proof of this connection. The right to build a monument is evidence of the host society's willingness to accept 'our' narrative or to confirm 'our' significance through national heroes. Such monuments usually create pilgrimage routes, while others are essential mainly for local migrant communities and diplomatic initiatives.

In terms of space, migrants' national monuments are connected with the homeland and the national narrative, mythology and pantheon, as well as the constellation of 'other' figures in the host public space. A monument is a result of the negotiation of ideas, but mainly the migrants' right to inhabit or visit the host society and to contribute to it through their national culture. 


\section{Acknowledgments}

The authors wish to express their gratitude to the National Science Fund at the Ministry of Education and Science of the Republic of Bulgaria. The fieldwork materials and the article are results of the following projects: 'Construction of National Cultural Heritage Abroad: Cross-Border Pilgrimage and Commemorative Practices' (2017-2021) and 'Cultural Heritage and Institutionalization of Bulgarian Historical and Contemporary Migrant Communities' beyond Europe' (2018-2022).

\section{Notes}

${ }^{1}$ See: az-jenata.bg/a/8-svobodno-vreme/8051-pomognete-na-initsiativata-da-prebroimpametnitsite-na-levski/; vesti.bg/bulgaria/obshtestvo/kolko-sa-pametnicite-na-vasillevski-2303211.

${ }^{2}$ The monument is located in the middle of a busy intersection in Sofia city centre, near where Vasil Levski was executed in February 1873. The project for building a monument started in 1878 , and the official opening was in 1895 , which made it one of the first monuments in the newly liberated Principality of Bulgaria. Its authors were Antonín Kolár (architect), Rudolf Weyr and František Novák (sculptors) and Abramo Peruchelli (stonecutter).

${ }^{3}$ The bust monument was unveiled in 1992 and it is the first to be erected in the Boris garden (on the Alley of Notable Bulgarians) after the political changes of 1989. In its place already was a monument to Georgi Atanasov, which has been removed. Its authors were Vladimir Ginovski (sculptor) and Ivan Bitrakov (architect). See: registersofia.bg/index. php? view=monument\&option=com_monuments\&formdata[id] $=1127 \&$ Itemid=140.

${ }^{4}$ The monument is located on the facade of the Bulgarian Theoretical Lyceum 'Vasil Levski' in Chisinau.

${ }^{5}$ Source: glaspress.rs/паметна-плоча-за-васил-левски-бе-откри/; novini.bg/sviat/ balkani/469321.

${ }^{6}$ Prof. Titz was awarded the Order of 'Sts Cyril and Methodius' by the President of the Republic of Bulgaria in 2009 on the occasion of the 130th anniversary of the establishment of diplomatic relations between Bulgaria and Austria for his great work in promoting Bulgarian culture and art in the Republic of Austria.

${ }^{7}$ Source: news.bg/world/borisov-otkri-pametnik-na-ivan-vazov-v-zagreb.html; trud.bg/ вижте-паметника-на-иван-вазов-в-загреб/; mfa.bg/embassies/croatia/news/18463. 
${ }^{8}$ In 2013, a delegation from Sopot led by the mayor Veselin Lichev visited Las Brenyas, where he signed a agreement to establish economic and cultural exchange between the two cities at a solemn ceremony on Bulgaria Square. The document is the first of its kind in the history of Bulgarian-Argentine relations and confirms the framework of cooperation between the two countries at the regional level. The first initiative for cultural exchange between the two cities is planned to be an exchange of monuments of famous artists from Bulgaria and Argentina. For Bulgaria this is Ivan Vazov, to be erected in Beriso, and for Argentina - the poet with Bulgarian roots, Mario Nestorov. For more, see: dnes.bg/obshtestvo/2013/11/30/sled-botev-i-levski-i-vazov-s-pametnik$\mathrm{v}$-arjentina.207902; mfa.bg/embassies/argentina/news/6005. To date there is no information about the future the two monuments.

${ }^{9}$ See the celebrations in 2019 and 2020 - mfa.bg/embassies/croatia/news/25462; mfa. bg/embassies/croatia/news/21970; facebook.com/watch/?v=341333256839200, as well as the commemoration by a government delegation led by the Minister of Education and Science of the Republic of Bulgaria in front of the monument in June 2018 - mfa. bg/embassies/croatia/news/18539.

${ }^{10}$ More about the ceremony see: http://bulgarian.cri.cn/61/2006/11/21/1@45966.htm. ${ }^{11}$ The sculpture in Kalofer was stolen in November 2010 but found and returned to its place the next year. See: frognews.bg/kultura/cherno-bqlo/plastmasov-botev-madechina-striaska-kalofer.html.

${ }^{12}$ For example see: bulgarian.cri.cn/1081/2013/12/15/1s129115.htm; https://m.president.bg/bg/news/rosen-plevneliev-v-pekin-balgariya-e-malka-ikonomika-no-edin-otgolemite-priyateli-na-kitay-v-es.

${ }^{13}$ See more: struma.com/obshtestvo/kitaiski-studenti-na-blagoevgradski-prepodavatelpyaha-na-bulgarski-ezik-pred_150166/; mfa.bg/embassies/china/news/18521; mfa.bg/ embassies/china/news/22057; http://china.edax.org/?p=3916.

${ }^{14}$ See: http://book-kiosk.ru/publication.php?id=3211; http://bgdiaspora.h3b.ru/1126.

${ }^{15}$ For example, see the celebration program in 2013: bci-russia.ru/afisha/болгарскиетрадиции-и-будители/?lang=RU; a review of the celebration in 2014: bci-russia.ru/ news/в-честь-дня-народных-будителей/?lang=RU, and an invitation for the event in 2016: https://www.facebook.com/moskva.bulgarite/posts/1862423057324262.

${ }^{16}$ For example, see: bci-russia.ru/afisha/вечер-памяти-ивана-вазова-пройдет-вбки/?lang=RU.

${ }^{17}$ The event starts with a reading of the writer's poems in Bulgarian and their translated versions in Russian, and continues with a visit to the monument of Sts Cyril and Methodius and the Russian grenadiers who fell in the battle of Pleven during the Russo-Turkish war 1877-1878. See: bci-russia.ru/afisha/190719/?lang=bg. 


\section{Lina Gergova, Yana Gergova}

${ }^{18}$ See, for example, a celebration of 24 May at the Sts Cyril and Methodius' monument (mfa.bg/embassies/russia/news/21978); a celebration of the National Day of the Republic of Bulgaria on 3 March in front of the monument to the grenadiers who fell in the battle of Pleven (mfa.bg/embassies/russia/news/20721) and the annual commemoration of the anniversary of the capitulation of Pleven in the Russo-Turkish Liberation War of 1877-1878 in front of the same monument (mfa.bg/embassies/russia/news/16393).

\section{References}

Anderson, Benedict. 2006. Imagined Communities: Reflections on the Origin and Spread of Nationalism. New York: Verso.

Aretov, Nikolay. 2006. Natsionalna mitologia i natsionalna literature. Syuzheti, izgrazhdashti balgarskata natsionalna identichnost v slovesnostta ot XVIII I XIX vek [National Mythology and National Literature. Building the Bulgarian National Identity in the Literature of the 18 and 19 Centuries Stories]. Sofia: Kralitsa Mab.

Baldassar, Loretta. 2006. Migration Monuments in Italy and Australia: Contesting Histories and Transforming Identities. Modern Italy, 11(1): 43-62.

Borisova, Mariyanka. 2019. Constructing Bulgarian Culture Heritage abroad: Mikulchitse (Czech Republic) as a Pilgrimage Centre. In: Gergova, L., Gergova, Y., Voskresenski, V. (eds.). Transborder Commemoration Routes and Rituals. Sofia: Paradigma, 77-90.

Boyer, M. Christine. 1994. The City of Collective Memory: Its Historical Imagery and Architectural Entertainments. Cambridge, MA: MIT Press.

De Cesari, Chiara, and Ann Rigney. 2013. Introduction. In: De Cesari, C. and Rigney, A. (eds.). Transnational Memory. Circulation, Articulation, Scales. Media and Cultural Memory/ Medien und kulturelle Erinnerung. Vol. 19. Berlin and Boston: Walter de Gruyter GmbH, pp. 1-25.

Eldarov, Svetolozar. 2002. Balgariya i Vatikana 1944-1989: Diplomaticheski, tsarkovni $i$ drugi otnosheniya [Bulgaria and Vatican 1944-1989: Diplomatic, Ecclesiastical and Other Relations]. Sofia: Logis.

Fortier, Anne-Marie. 2000. Migrant Belongings: Memory, Space, Identity. London: Bloomsbury Academic.

Gergova, Lina, and Yana Gergova. 2017. Cultural Heritage on Foreign Territory: Bulgarian Monuments in Bucharest and Rome. Papers of BAS. Humanities and Social Sciences. Sofia, Prof. Marin Drinov Publishing House of BAS, Vol. 4, No 1, 3-17.

Gergova, Yana. 2019. Konstruirane na natsionalno kulturno nasledstvo zad granitsa: "Balgarskite mesta" v Italia [Constructing of National Cultural Heriatge Abroad: "Bulgarian Places" in Italy]. In: Balázs, L. G., Farkas, M., Majoros, H. (eds.). 
Balgaristichni cheteniya. Seged 2019 [Bulgarian Readings - Szeged 2019]. Szeged: JATEPress, pp. 407-414.

Grigorov, Grigor. 2007. Poslesmartniyat 'zhivot' na geroite [After Death 'Live' of the Heroes]. - Nenov, N., R. Malchev, K. Rangochev (Eds.). Etnologiya i demonologiya [Ethnology and Demonology]. Sofia: ROD, 114-130.

Halbwachs, Maurice. 1992. On Collective Memory. Chicago: The University of Chicago Press.

Johnson, Nuala C. 1994. Sculpting Heroic Histories: Celebrating the Centenary of the 1798 Rebellion in Ireland. Transactions of the Institute of British Geographers, 19: 78-93.

Johnson, Nuala C. 1995. Cast in Stone: Monuments, Geography and Nationalism. Environment and Planning D: Society and Space, 13: 51-65.

Johnson, Nuala C. 2002. Mapping monuments: the shaping of public space and cultural identities. Visual Communication, 1(3): 293-298.

Marschall, Sabine (ed). 2020. Public Memory in the Context of Transnational Migration and Displacement. Migrants and Monuments. (eBook): Palgrave Macmillan [https://doi.org/10.1007/978-3-030-41329-3].

Matanova, Tanya. 2017. Balgarskoto nedelno uchilishte “Sv. Vmchk Georgi Zograf” v Solun - institutsiya, konsolidatsionen tsentar, mediator na balgarskoto kulturno nasledtsvo [Bulgarian Sunday School “St. George Zograf” in Thessaloniki. Institution, Consolidation Center, Mediator of the Bulgarian Cultural Heritage]. Balgarski folklore [Bulgarian Folklore], 3: 355-371.

Nikolov, Rayko. 1998. Na goresh post v Rim: Sled izstrelite sreshtu papata [On a Hot Post in Rome: After the Shootings Against the Pope]. Sofia: UPH “St. Kliment Ohridski”.

Radstone, Susannah. 2011. What Place Is This? Transcultural Memory and the Locations of Memory Studies. Parallax, 17 (4), 109-123.

Roudometof, Victor. 2002. Collective Memory, National Identity, and Ethnic Conflict: Greece, Bulgaria, and the Macedonian Question. Westport: Greenwood Publishing Group.

Smith, Anthony. 1995. Nations and Nationalism in a Global Era. Cambridge: Polity.

Vaughan, Laura. 2018. Mapping Society: The Spatial Dimensions of Social Cartography. London: UCL Press.

Voskresenski, Valentin. 2017. Pametni mesta v migratsiya i pochitane na natsionalni geroi [Places of Memory in Migration and Honoring of National Heroes]. Penchev, Vl. et al. Kulturno nasledstvo v migratsiya. Modeli na konsolidatsiya $i$ institutsionalizatsiya na balgarskite obshnosti v chuzhbina [Cultural Heritahe in Migration. Models of Consolidation and Institutionalization of the Bulgarian Communities Abroad]. Sofia: Paradigma. 


\section{Lina Gergova, Yana Gergova}

Voskresenski, Valentin, and Nikolai Vukov. 2017. The Bulgarian Associations in Spain and the Institutional Aspects in Maintaining Cultural Heritage in Migration. In N. Vukov et al. (eds.). Cultural Heritage in Migration. Sofia: Paradigma, 211-239. Vukov, Nikolay, and Mariyanka Borisova. 2017. The Festive Days of the Bulgarian Community in Chicago - Models of Cultural Heritage in Migration. Papers of BAS. Humanities and Social Sciences. Sofia, Prof. Marin Drinov Publishing House of BAS, Vol. 4, No 1, 18-37.

Wolf, Caroline 'Olivia’ M. 2017. Migrant Monuments, Monumental Migrants: São Paulo’s Sculptural Homage to Syrian-Lebanese Friendship and the Crafting of Transnational Identity in Centennial Brazil. TAREA, 4(4), 120-152.

Wolf, Caroline 'Olivia' M. 2020. Memorializing Migration: Immigrant Patronage, Public Memory and the Syrian Centennial Monument to Argentina (1910). In: Marschall, S. (ed). Public Memory in the Context of Transnational Migration and Displacement: Migrants and Monuments. (eBook): Palgrave Macmillan [https:// doi.org/10.1007/978-3-030-41329-3], 31-60.

Lina Gergova, PhD, Assistant Professor at the Institute of Ethnology and Folklore Studies with Ethnographic Museum, Bulgarian Academy of Sciences. Her research interests are in the field of ethnic stereotypes, migrations and cultural heritage, urban festivity and national commemorative traditions.

Yana Gergova, PhD, Assistant Professor at the Institute of Ethnology and Folklore Studies with Ethnographic Museum, Bulgarian Academy of Sciences. Her research interests are in the field of religious architecture, imagery and ritual practices, contemporary religious objects and images, religious practices, pilgrimage, cult of saints, religiosity and places of worship among new migrant communities. 